\title{
IMPLEMENTASI ALGORITMA TRIANGLE CHAIN CIPHER DAN GOST PADA PENGAMANAN CITRA DIGITAL
}

\section{Vivi Irda Anggraini}

Program Studi Teknik Informatika, Universitas Budi Darma, Sumatera Utara, Indonesia Email: viviirda28@gmail.com

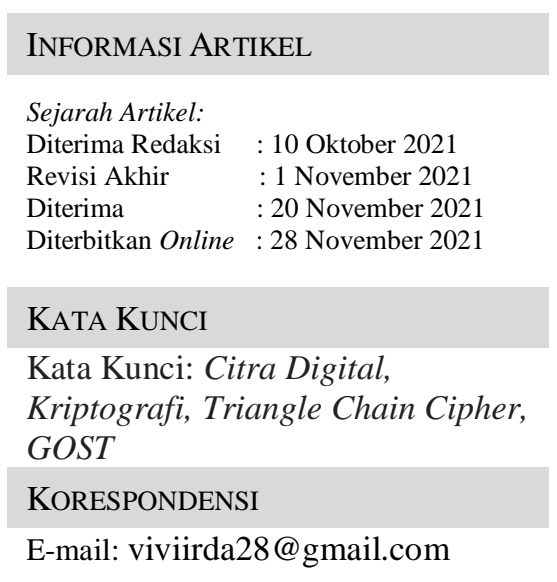

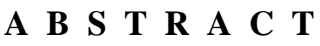

Keamanan citra digital penting untuk dijaga agar informasi tersebut tetap utuh dan terjamin. Keamanan citra digital dapat dilakukan dengan pemanfaatan teknik kriptografi. Teknik kriptografi dapat menyandikan citra digital dengan mengenkripsikannya ke dalam bentuk sandi-sandi yang tidak dipahami. Algoritma Triangle Chain Cipher dan GOST adalah salah satu algoritma yang dapat diandalkan dalam mewujudkan teknik kriptografi. Kombinasi kedua algoritma ini akan menghasilkan tingkat keamanan yang lebih tinggi terhadap pengamanan citra digital karena dapat menyandikannya ke bentuk sandi dengan proses yang cukup rumit sehingga akan mempersulit kriptanalis untuk mengaksesnya. Penelitian ini akan menguraikan proses enkripsi berdasarkan triangle chain cipher kemudian di enkripsi lagi berdasarkan GOST. Hal ini dilakukan sebagai upaya untuk meminimalisir tindakan-tindakan penyalahgunaan citra digital .
\end{abstract}

\begin{abstract}
The security of digital images is important to maintain so that the information remains intact and guaranteed. The security of digital images can be done by utilizing cryptographic techniques. Cryptographic techniques can encode digital images by encrypting them in the form of passwords that are not understood. The Triangle Chain Cipher and GOST Algorithms are one of the algorithms that can be relied upon in realizing cryptographic techniques. The combination of these two algorithms will result in a higher level of security against digital image security because it can encode it into a password with a fairly complex process that will make it difficult for cryptanalysts to access it. This research will describe the encryption process based on the triangle chain cipher and then encrypted again based on GOST. This is done as an effort to minimize acts of abuse of digital images.
\end{abstract}

\section{PENDAHULUAN}

Citra digital merupakan gambaran atau kemiripan dari suatu objek yang dapat diolah komputer. Umumnya citra memiliki data yang cukup besar sehingga membutuhkan daya komputasi yang besar pula. Citra digital memiliki berbagai informasi yang dapat menjadi penting apabila didalamnya terdapat informasi berharga. Foto pribadi dan dokumen penting lainnya merupakan salah satu citra digital yang bersifat rahasia yang apabila diakses pihak yang tidak bertanggung jawab tentunya akan berbahaya dan merugikan pemiliknya [1]. Salah satu teknik yang dapat digunakan untuk mengamankan suatu citra digital adalah menggunakan teknik kriptografi.

Kriptografi merupakan ilmu yang mempelajari tentang teknik matematika yang berhubungan dengan kerahasiaan, keamanan data, dan integritas data. Pentingnya kriptografi untuk keamanan data berkaitan dengan penggunaan komputer. Menjaga kerahasiaan, integritas data, otentikasi, dan nirpenyangkalan merupakan tujuan kriptografi [2].

Metode kriptografi yang akan digunakan untuk mengamankan ctra digital adalah algoritma Triangle Chain Cipher dan GOST, dimana proses algoritma GOST menggunakan 64 bit block cipher dan 256 bit kunci, sampai saat ini 
kelemahan GOST dikarenakan key schedule yang sederhana [3], sehingga penulis mengkombinasikan dengan algoritma triangle chain cipher agar mengoptimalkan keamanan citra digital. Proses enkripsi dan dekripsi pada algoritma triangle chain cipher dilakukan secara berantai berdasarkan perkalian nilai kunci dan factor pengali yang dilakukan secara ganda sehingga hasil yang didapat jauh berbeda dengan pesan asli.

\section{METODOLOGI PENELITIAN}

\subsection{Aplikasi Algoritma Crochemore Perrin}

Algoritma Crochemore-Perrin yang sering juga disebut dengan algoritma Two Way Algorithm, atau Algoritma Dua Arah dipublikasikan Maxime Crochemore dan Dominique Perrin pada tahun 1991. Algoritma ini memfaktorkan pattern menjadi dua bagian patternkanan dan patternkiri. Fase pencocokan pada algoritma ini tediri dari dua bagian, pertama pencocokan karakter patternkanan dari kiri kekanan lalu pencocokan karakter patternkiri dari kanan kekiri.

\subsection{String Matching}

String Matching adalah proses pencarian semua kemunculan query yang selanjutnya disebut pattern ke dalam string yang lebih panjang (teks). Pattern dilambangkan dengan $x=x[0 . . m-1]$ dan panjangnya adalah $\mathrm{m}$. Teks dilambangkan dengan $\mathrm{y}=\mathrm{y}[0 . . \mathrm{n}-1]$ dan panjangnya adalah $\mathrm{n}$.

\subsection{Aplikasi}

Aplikasi itu sebenernya adalah program, tetapi berbeda dari titi pandang. Program adalah istilah yang biasa dipakai oleh pembuat program, sedangkan aplikasi adalah istilah dari sisi pemakai (user). Program adalah yang ditulis oleh pemogram, sedangkan aplikasi adalah hasil terjemahan program, berupa kode yang di pahami oleh mesin [6]..

\section{ANALISA DAN PEMBAHASAN}

\subsection{Analisa}

Citra matematis adalah citra berbentuk abstrak yang di dalamnya terdapat fungsi kontinu dan fungsi diskrit. Citra berfungsi diskrit atau citra digital inilah yang dapat diolah komputer. Sebuah matriks yang terdiri dari kolom dan baris dapat mewakili sebuah citra digital yang dimana perpotongan antara kolom dan baris disebut piksel [9].

\subsection{Analisa}

Penerapan pengkombinasiaan algoritma triangle chain cipher dan GOST diimplementasi pada citra grayscale berukuran 2x4 yang telah dipilih sebagai contoh. Langkah-langkah yang dilakukan pada penerapan kombinasi kedua algoritma ini mengikuti aturan yang ditetapkan pada masing-masing algoritma. Sebelum proses enkripsi dilakukan, terlebih dahulu ubah citra warna menjadi grayscale menggunakan software photoshop, selanjutnya ambil nilai piksel pada setiap elemen piksel menggunakan software matlab. Kemudian lakukan pembacaan nilai kunci dan pembentukan tabel faktor pengali. Selanjutnya enkripsi citra digital rahasia (plainimage) berdasakan algoritma triangle chain cipher, kemudian binerkan cipherimage hasil dari pengamanan algoritma triangle chain cipher dan enkripsi kembali menggunakan algoritma GOST.

Proses enkripsi pada algoritma triangle chain cipher dilakukan secara berantai berdasarkan perkalian nilai kunci dan faktor pengali yang dilakukan melalui dua tahapan yaitu segitiga pertama dan segitiga kedua. Sedangkan proses enkripsi pada algoritma GOST dilakukan perblok. Proses enkripsi dan dekripsi dilakukan sebanyak 32 putaran yang menggunakan 64 bit blok cipher dan 256 bit kunci, serta menggunakan 8 buah tabel S-BOX

\section{Contoh Kasus}

Berikut ini diuraikan penerapan algoritma triangle chain cipher dan algoritma GOST dalam mengamankan sebuah citra grayscale berekstensi .jpg dengan resolusi 186 x 138.

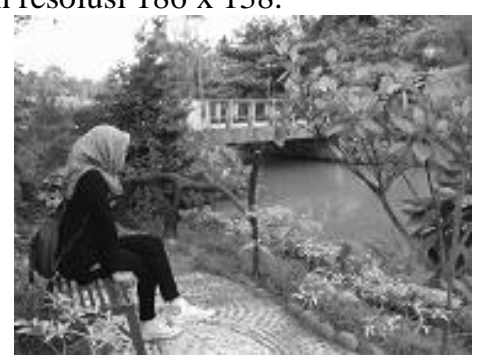

Gambar 3.1 Plainimage Resolusi 138 x 184

Berdasarkan plainimage diatas, maka akan diambil delapan piksel sebagai contoh perhitungan manual. Delapan piksel tersebut akan diambil nilai desimal pada setiap piksel. 

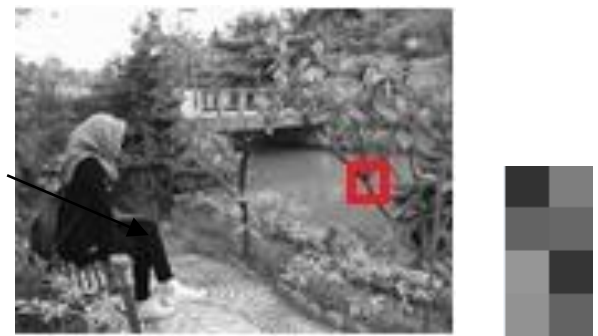

Gambar 3.2 Plainimage Contoh Sebanyak 8 Piksel

Nilai piksel dari delapan piksel plainimage contoh diatas di ambil dengan menggunakan software matlab, sehingga diperoleh:

\begin{tabular}{cc} 
Tabel 3.1 Piksel Citra Conto \\
\hline \multicolumn{3}{c}{ Piksel } \\
\hline 50 & 126 \\
99 & 103 \\
150 & 53 \\
146 & 99 \\
\hline
\end{tabular}

Berdasarkan tabel 3.1 diatas, maka dapat dilihat nilai desimal plainimage adalah 50, 126, 99, 103, 150, 53, 146, 99 1. Proses enkripsi berdasarkan algoritma triangle chain cipher dan GOST

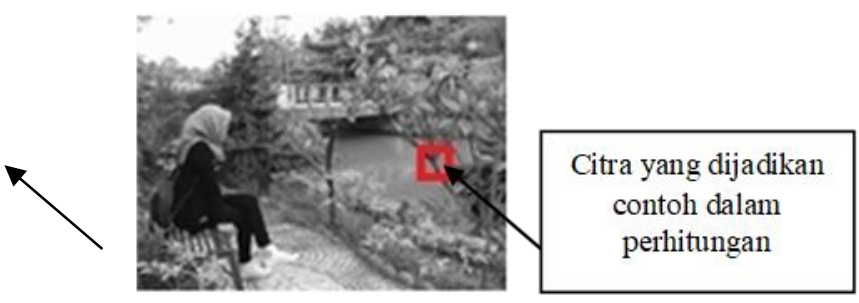

Gambar 3.3 Contoh Citra Grayscale

a. Proses enkripsi algoritma triangle chain cipher

Proses enkripsi algoritma triangle chain cipher dilakukan dengan dua tahap yaitu enkripsi segitiga pertama dan enkripsi segitiga kedua yang menghasilkan cipher akhir. Berikut ini uraian proses enkripsi :

1) Matrix enkripsi segitiga pertama

$$
\begin{aligned}
& \text { Plainimage }=50,126,99,103,150,53,146,99 \\
& \mathrm{~N}=8 \\
& \mathrm{~K}=3 \\
& \mathrm{R}=1,2,3,4,5,6,7,8 \\
& \text { Untuk baris pertama }(i=1) \text {, maka : } \\
& \mathrm{M}_{1,1}=(\mathrm{P}[1]+3 * \mathrm{R}[1] \bmod 256 \\
& =\left(50+3^{*}(1)\right) \bmod 256 \\
& =(50+3) \bmod 256 \\
& =53 \bmod 256 \\
& =53 \\
& \mathrm{M}_{1,2}=(\mathrm{P}[2]+3 * \mathrm{R}[1] \bmod 256 \\
& =(126+3 *(1)) \bmod 256 \\
& =(126+3) \bmod 256 \\
& =129 \bmod 256 \\
& =129 \\
& \mathrm{M}_{1,3}=(\mathrm{P}[3]+3 * \mathrm{R}[1] \bmod 256 \\
& =(99+3 *(1)) \bmod 256 \\
& =(99+3) \bmod 256 \\
& =102 \bmod 256 \\
& =102 \\
& \mathrm{M}_{1,4}=(\mathrm{P}[4]+3 * \mathrm{R}[1] \bmod 256 \\
& =(103+3 *(1)) \bmod 256 \\
& =(103+3) \bmod 256 \\
& =106 \bmod 256 \\
& =106
\end{aligned}
$$




$$
\begin{aligned}
\mathrm{M}_{1,5} & =(\mathrm{P}[5]+3 * \mathrm{R}[1] \bmod 256 \\
& =(150+3 *(1)) \bmod 256 \\
& =(150+3) \bmod 256 \\
& =153 \bmod 256 \\
& =153 \\
\mathrm{M}_{1,6} & =(\mathrm{P}[6]+3 * \mathrm{R}[1] \bmod 256 \\
& =(53+3 *(1)) \bmod 256 \\
& =(53+3) \bmod 256 \\
& =56 \bmod 256 \\
& =56 \\
\mathrm{M}_{1,7} & =(\mathrm{P}[7]+3 * \mathrm{R}[1] \bmod 256 \\
& =(146+3 *(1)) \bmod 256 \\
& =(146+3) \bmod 256 \\
& =149 \bmod 256 \\
& =149 \\
& =(\mathrm{P}[8]+3 * \mathrm{R}[1] \bmod 256 \\
& =(99+3 *(1)) \bmod 256 \\
& =(99+3) \bmod 256 \\
& =102 \bmod 256 \\
& =102
\end{aligned}
$$

Hasil dari enkripsi baris pertama adalah :

$50,126,99,103,150,53,146,99 \quad \rightarrow \mathrm{i}=0$

$\mathbf{5 3}, 129,102,106,153,56,149,102 \quad \rightarrow \mathrm{i}=1$

Hasil enkripsi dari baris pertama $(\mathrm{i}=1)$ akan digunakan sebagai plainimage pada proses kedua $(\mathrm{i}=2)$, dimana $\mathrm{j}$ $\geq \mathrm{i}$, sehingga $: \mathrm{i}=2, \mathrm{j}=2$

$$
\begin{aligned}
\mathrm{M}_{2,2} & =(\mathrm{P}[2]+3 * \mathrm{R}[2] \bmod 256 \\
& =(129+3 *(2)) \bmod 256 \\
& =(129+6) \bmod 256 \\
& =135 \bmod 256 \\
& =135 \\
\mathrm{M}_{2,3} & =(\mathrm{P}[3]+3 * \mathrm{R}[2] \bmod 256 \\
& =(102+3 *(2)) \bmod 256 \\
& =(102+6) \bmod 256 \\
& =108 \bmod 256 \\
& =108 \\
& =(\mathrm{P}[4]+3 * \mathrm{R}[2] \bmod 256 \\
& =(106+3 *(2)) \bmod 256 \\
& =(106+6) \bmod 256 \\
& =112 \bmod 256 \\
& =112 \\
\mathrm{M}_{2,5} & =(\mathrm{P}[5]+3 * \mathrm{R}[2] \bmod 256 \\
& =(153+3 *(2)) \bmod 256 \\
& =(153+6) \bmod 256 \\
& =159 \bmod 256 \\
& =159 \\
& =(\mathrm{P}[6]+3 * \mathrm{R}[2] \bmod 256 \\
& =(56+3 *(2)) \bmod 256 \\
& =(56+6) \bmod 256 \\
& =62 \bmod 256 \\
& =62 \\
\mathrm{M}_{2,6} & =(\mathrm{P}[7]+3 * \mathrm{R}[2] \bmod 256 \\
& =(149+3 *(2)) \bmod 256 \\
& =(149+6) \bmod 256 \\
& =155 \bmod 256 \\
& =155 \\
& =(\mathrm{P}[8]+3 * \mathrm{R}[2] \bmod 256 \\
& =(102+3 *(2)) \bmod 256 \\
& =(102+6) \bmod 256 \\
& =108 \bmod 256 \\
& =108 \\
\mathrm{M}_{2,7} &
\end{aligned}
$$

Hasil dari enkripsi baris kedua adalah :

$50,126,99,103,150,53,146,99 \quad \rightarrow \mathrm{i}=0$ 
53, 129, 102, 106, 153, 56, 149, $102 \quad \rightarrow \mathrm{i}=1$

135, 108, 112, 159, 62, 155, $108 \rightarrow \mathrm{i}=2$

Baris selanjutnya dapat dicari dengan cara yang sama seperti diatas, sehingga di dapatkan cipher sebagai berikut :

\begin{tabular}{ccccccccc}
\multicolumn{7}{c}{ Tabel 3.2 Hasil Enkripsi Segitiga Pertama } \\
\hline $\begin{array}{c}\mathrm{M} \\
\mathrm{i}^{\mathrm{j}}\end{array}$ & 1 & 2 & 3 & 4 & 5 & 6 & 7 & 8 \\
\hline 0 & 50 & 126 & 99 & 103 & 150 & 53 & 146 & 99 \\
1 & 53 & 129 & 102 & 106 & 153 & 56 & 149 & 102 \\
2 & & 135 & 108 & 112 & 159 & 62 & 155 & 108 \\
3 & & & 117 & 121 & 168 & 71 & 164 & 117 \\
4 & & & & 133 & 180 & 83 & 176 & 129 \\
5 & & & & & 195 & 98 & 191 & 144 \\
6 & & & & & & 116 & 209 & 162 \\
7 & & & & & & & 230 & 183 \\
8 & & & & & & & 207
\end{tabular}

Hasil enkripsi segitiga pertama :

Sesuai dengan formula $\mathrm{M}_{\mathrm{ij}}$ huruf pertama dari masing-masing baris sebanyak satu karakter pada nilai $\mathrm{j}=(\mathrm{N}+\mathrm{i})-\mathrm{N}$ akan menjadi chipherimage pada proses enkripsi segitiga pertama :

53, 129, 102, 106, 153, 56, 149, 102 hasil dari baris pertama $\mathrm{i}=1$ dan $\mathrm{j}=(8+1)-8=1$

135, 108, 112, 159, 62, 155, 108 hasil dari baris kedua $\mathrm{i}=2$ dan $\mathrm{j}=(8+2)-8=2$

117, 121, 168, 71, 164, 117 hasil dari baris ketiga

$\mathrm{i}=3$ dan $\mathrm{j}=(8+3)-8=3$

113, 180, 83, 176, 129 hasil dari baris keempat

$\mathrm{i}=4 \operatorname{dan} \mathrm{j}=(8+4)-8=4$

195, 98, 191, 144 hasil dari baris kelima

$\mathrm{i}=5$ dan $\mathrm{j}=(8+5)-8=5$

116, 209, 162 hasil dari baris keenam

$\mathrm{i}=6 \operatorname{dan} \mathrm{j}=(8+6)-8=6$

$\mathrm{i}=7$ dan $\mathrm{j}=(8+7)-8=7$

230, 183 hasil dari baris ketujuh

$i=8$ dan $j=(8+8)-8=8$

207 hasil dari baris kedelapan

Sehingga cipherimage yang di hasilkan adalah :

53, 135, 117, 113, 195, 116, 230, 207

Tabel 3.3 Cipherimage Enkripsi Segitiga Pertama

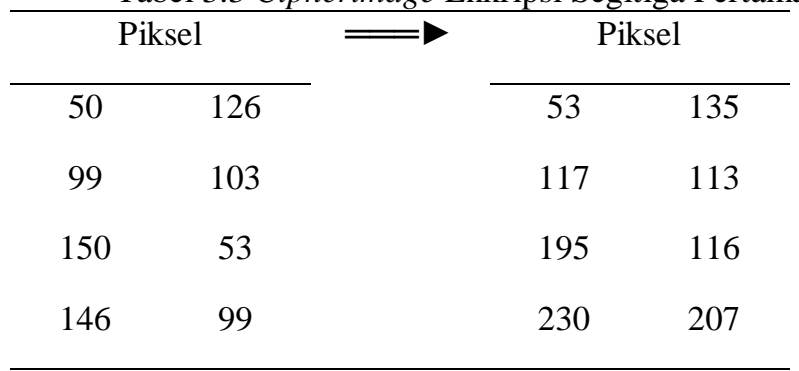

Citra Asli

Cipherimage

enkripsi segitiga pertama 


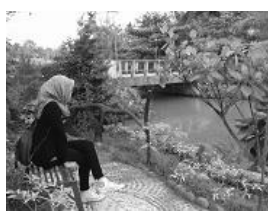

Gambar 3.4 Cipherimage Enkripsi Segitiga Pertama
Citra Asli
Cipherimage

enkripsi segitiga pertama

2. Matriks enkripsi segitiga kedua

Langkah-langkah yang dilakukan pada enkripsi segitiga kedua hampir sama dengan enkripsi segitiga pertama.

Pada proses ini menggunakan faktor pengali dan kunci yang digunakan pada enkripsi segitiga pertama, dan cipherimage hasil enkripsi dari segitiga pertama menjadi plainimage untuk proses enkripsi segitiga kedua, yaitu :

Plainimage $=53,135,117,133,195,116,230,207$

$$
\begin{array}{ll}
\mathrm{N} & =8 \\
\mathrm{~K} & =3 \\
\mathrm{R} & =1,2,3,4,5,6,7,8
\end{array}
$$

Untuk baris pertama $(\mathrm{i}=1)$, maka :

$\mathrm{M}_{1,1} \quad=(\mathrm{P}[1]+3 * \mathrm{R}[1] \bmod 256$

$=(53+3 *(1)) \bmod 256$

$=(53+3) \bmod 256$

$=56 \bmod 256$

$=56$

$\mathrm{M}_{1,2}=(\mathrm{P}[2]+3 * \mathrm{R}[1] \bmod 256$

$=(135+3 *(1)) \bmod 256$

$=(135+3) \bmod 256$

$=138 \bmod 256$

$=138$

$\mathrm{M}_{1,3}=(\mathrm{P}[3]+3 * \mathrm{R}[1] \bmod 256$

$=(117+3 *(1)) \bmod 256$

$=(117+3) \bmod 256$

$=120 \bmod 256$

$=120$

$\mathrm{M}_{1,4}=(\mathrm{P}[4]+3 * \mathrm{R}[1] \bmod 256$

$=(133+3 *(1)) \bmod 256$

$=(133+3) \bmod 256$

$=136 \bmod 256$

$=136$

$\mathrm{M}_{1,5}=(\mathrm{P}[5]+3 * \mathrm{R}[1] \bmod 256$

$=(195+3 *(1)) \bmod 256$

$=(195+3) \bmod 256$

$=198 \bmod 256$

$=198$

$\mathrm{M}_{1,6}=(\mathrm{P}[6]+3 * \mathrm{R}[1] \bmod 256$

$=(116+3 *(1)) \bmod 256$

$=(116+3) \bmod 256$

$=119 \bmod 256$

$=119$

$\mathrm{M}_{1,7}=(\mathrm{P}[7]+3 * \mathrm{R}[1] \bmod 256$

$=(230+3 *(1)) \bmod 256$

$=(230+3) \bmod 256$

$=233 \bmod 256$

$=233$

$\mathrm{M}_{1,8} \quad=(\mathrm{P}[8]+3 * \mathrm{R}[1] \bmod 256$

$=(207+3 *(1)) \bmod 256$

$=(207+3) \bmod 256$

$=210 \bmod 256$

$=210$

Hasil dari enkripsi baris pertama adalah :

53, 135, 117, 113, 195, 116, 230, 207

$56,138,120,136,198,119,233,210$

$\rightarrow \mathrm{i}=0$

$\rightarrow \mathrm{i}=1$ 
Hasil enkripsi dari baris pertama $(i=1)$ akan digunakan sebagai plainimage pada proses enkripsi baris kedua, dimana nilai $\mathrm{j} \leq(\mathrm{N}+1)-\mathrm{i}$,

$$
\begin{aligned}
\text { sehingga }: \mathrm{i}= & 2 ; \mathrm{j} \leq(8+1)-2 \rightarrow \mathrm{j} \leq 7 \\
\mathrm{M}_{2,1} & =(\mathrm{P}[1]+3 * \mathrm{R}[2] \bmod 256 \\
& =(56+3 *(2)) \bmod 256 \\
& =(56+6) \bmod 256 \\
& =62 \bmod 256 \\
& =62 \\
& =(\mathrm{P}[2]+3 * \mathrm{R}[2] \bmod 256 \\
& =(138+3 *(2)) \bmod 256 \\
& =(138+6) \bmod 256 \\
\mathrm{M}_{2,2} & =144 \bmod 256 \\
& =144 \\
& =(\mathrm{P}[3]+3 * \mathrm{R}[2] \bmod 256 \\
& =(120+3 *(2)) \bmod 256 \\
& =(120+6) \bmod 256 \\
& =126 \bmod 256 \\
& =126 \\
\mathrm{M}_{2,3} & =(\mathrm{P}[4]+3 * \mathrm{R}[2] \bmod 256 \\
& =(136+3 *(2)) \bmod 256 \\
& =(136+6) \bmod 256 \\
& =142 \bmod 256 \\
& =142 \\
& =(\mathrm{P}[5]+3 * \mathrm{R}[2] \bmod 256 \\
& =(198+3 *(2)) \bmod 256 \\
& =(198+6) \bmod 256 \\
& =204 \bmod 256 \\
& =204 \\
& =(\mathrm{P}[6]+3 * \mathrm{R}[2] \bmod 256 \\
& =(119+3 *(2)) \bmod 256 \\
& =(119+6) \bmod 256 \\
& =125 \bmod 256 \\
& =125 \\
& =(\mathrm{P}[7]+3 * \mathrm{R}[2] \bmod 256 \\
& =(233+3 *(2)) \bmod 256 \\
& =(233+6) \bmod 256 \\
& =239 \bmod 256 \\
& =239 \\
\mathrm{M}_{2,7} & \\
\mathrm{M}_{2,6} & \\
\mathrm{M}_{2,5} &
\end{aligned}
$$

Hasil dari enkripsi baris kedua adalah :
53, 135, 117, 113, 195, 116, 230, 207
56, 138, 120, 136, 198, 119, 233, 210
$62,144,126,142,204,125,239$

$$
\begin{aligned}
& \rightarrow \mathrm{i}=0 \\
& \rightarrow \mathrm{i}=1 \\
& \rightarrow \mathrm{i}=2
\end{aligned}
$$

Baris selanjutnya dapat dicari dengan cara yang sama seperti diatas, sehingga di dapatkan cipher sebagai berikut :

\begin{tabular}{cccccccccc}
\multicolumn{8}{c}{ Tabel 3.4 Hasil Enkripsi Segitiga Kedua } \\
\hline $\begin{array}{c}\mathrm{M} \\
\mathrm{i}^{\mathrm{j}}\end{array}$ & 1 & 2 & 3 & 4 & 5 & 6 & 7 & 8 \\
\hline 0 & 53 & 135 & 117 & 133 & 195 & 116 & 230 & 207 \\
1 & 56 & 138 & 120 & 136 & 198 & 119 & 233 & 210 \\
2 & 62 & 144 & 126 & 142 & 204 & 125 & 239 & \\
3 & 71 & 153 & 135 & 151 & 213 & 134 & & \\
4 & 83 & 165 & 147 & 163 & 225 & & & \\
5 & 98 & 180 & 162 & 178 & & & & \\
6 & 116 & 198 & 180 & & & & & \\
7 & 137 & 219 & & & & & & \\
8 & 161 & & & & & & & \\
\hline
\end{tabular}


Hasil enkripsi segitiga kedua :

Sesuai dengan formula $\mathrm{M}_{\mathrm{ij}}$ krakter terakhir dari masing-masing baris sebanyak satu karakter pada nilai $\mathrm{j}=(\mathrm{N}+1)$ i akan menjadi chipherimage pada proses enkripsi segitiga kedua :

$56,138,120,136,198,119,233,210$ hasil dari baris pertama

$\mathrm{i}=1$ dan $\mathrm{j}=(8+1)-1=8$

$62,144,126,142,204,125, \mathbf{2 3 9}$ hasil dari baris kedua

$\mathrm{i}=2$ dan $\mathrm{j}=(8+1)-2=7$

$71,153,135,151,213, \mathbf{1 3 4}$

$\mathrm{i}=3$ dan $\mathrm{j}=(8+1)-3=6$

$83,165,147,163,225$

hasil dari baris ketiga

$\mathrm{i}=4$ dan $\mathrm{j}=(8+1)-4=5$

$98,180,162,178$

hasil dari baris keempat

hasil dari baris kelima

$\mathrm{i}=5$ dan $\mathrm{j}=(8+1)-5=4$

$116,198,180$

$\mathrm{i}=6$ dan $\mathrm{j}=(8+1)-6=3$

137,219

hasil dari baris keenam

$\mathrm{i}=7$ dan $\mathrm{j}=(8+1)-7=2$

161

hasil dari baris ketujuh

hasil dari baris kedelapan

$\mathrm{i}=8$ dan $\mathrm{j}=(8+1)-8=1$

Sehingga cipherimage yang di hasilkan adalah :

$161,219,180,178,225,134,239,210$

Tabel 3.5 Cipherimage Enkripsi Segitiga Kedua

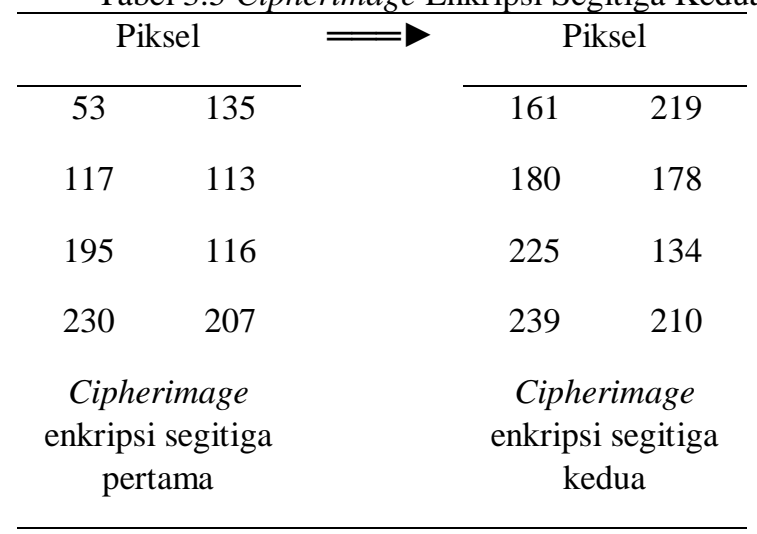

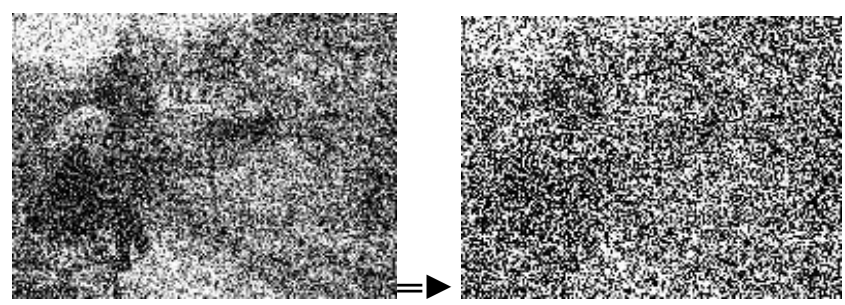

Gambar 3.5 Cipherimage Enkripsi Segitiga Kedua

$\begin{array}{lll}\begin{array}{l}\text { Cipherimage enkripsi segitiga } \\ \text { pertama }\end{array} & \begin{array}{l}\text { Cipherimage enkripsi segitiga } \\ \text { kedua }\end{array}\end{array}$

\section{IMPLEMENTASI}

\subsection{Hasil}

Implementasi adalah proses penggunaan aplikasi dan menguji aplikasi yang telah dibuat sesuai dengan rancangan. Adapun kebutuhan sistem dalam pembahasan ini dibagi menjadi 2 bagian yaitu, kebutuhan perangkat keras dan kebutuhan perangkat lunak.

\section{Tampilan Program}

Tampilan program aplikasi terdiri dari tampilan menu utama, tampilan form enkripsi, tampilan form dekripsi dan tampilan form info. 


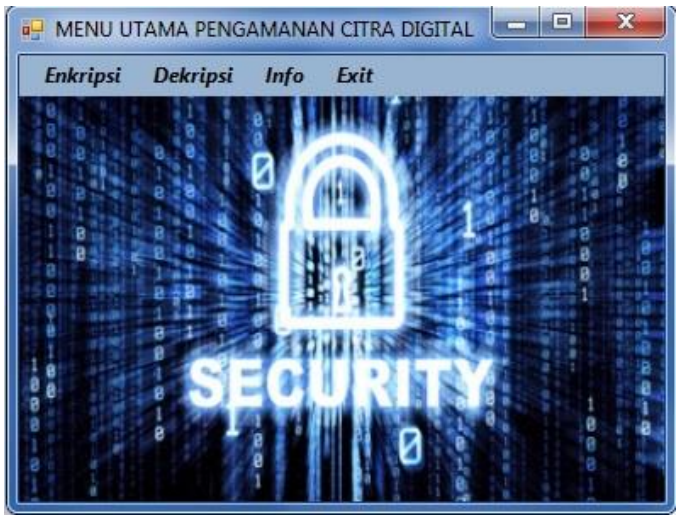

Gambar 4.1 Tampilan Menu Utama Aplikasi

1. Proses enkripsi citra digital

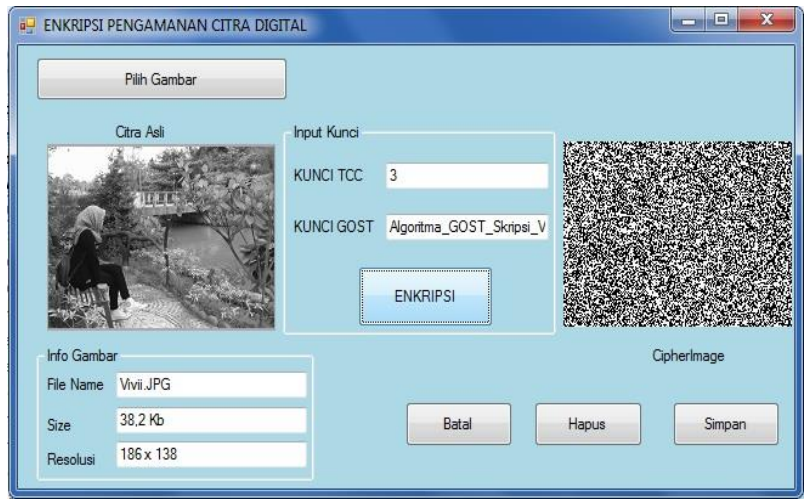

Gambar 4.2 Tampilan Form Enkripsi

2. Proses dekripsi citra digital

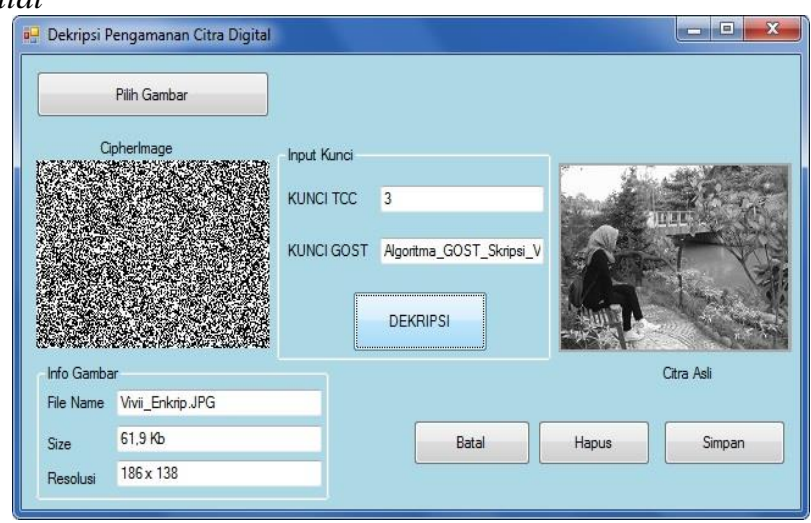

Gambar 4.3 Tampilan Form Dekripsi

\section{KESIMPULAN}

Berdasarkan hasil penerapan algoritma Triangle Chain Cipher dan GOST pada pengamanan citra digital yang telah dilakukan, penulis dapat menarik kesimpulan sebagai berikut:

1. Penerapan kombinasi algoritma triangle chain cipher dan algoritma GOST untuk meningkatkan keamanan citra digital dan meningkatkan kerahasiaan citra dimana citra tersebut disampaikan melalui citra lain sehingga tidak disalah gunakan oleh orang tidak bertanggung jawab.

2. Prosedur pengkombinasian algoritma triangle chain cipher dan algoritma GOST dilakukan secara berurut, dimana algoritma triangle chain cipher digunakan untuk menyandikan citra digital pertama kali, sedangkan algoritma GOST digunakan untuk menyandikan kembali citra digital.

3. Perancangan aplikasi yang dibangun ini sangat membantu dan mempermudah proses penyandian citra digital serta proses pengembalian citra digital kebentuk asli. Aplikasi yang dibangun berjalan normal pada sistem operasi windows 7 serta bahasa pemrograman yang digunakan dalam bahasa pemrograman visual basic 2008 . 


\section{REFERENCES}

[1] D. Ratnasari et al., "Enkripsi Citra Digital Menggunakan Kombinasi Algoritme Hill Cipher Dan Chaos Map Dengan Penerapan Teknik Selektif Pada Bit Msb," J. Teknol. TECHNOSCIENTIA, vol. 10, no. 1, hal. 109117, 2017.

[2] E. Setyaningsih, Kriptografi \& Implementasi Menggunakan MATLAB. yogyakarta: Andi, 2015.

[3] J. Siregar, “Implementasi Keamanan Data Teks Dengan Algoritma Gost Dan Rot13,” J. INFOTEK, vol. 1, no. 2, hal. 68-73, 2016.

[4] R. Syahputra, "Penerapan Mode Operasi Cipher Block Chaining Dan Metode Lsb-1 Dalam Pengamanan Data Teks," J. Pelita Inform., vol. 16, no. Juli, hal. 318-321, 2017.

[5] R. Munir, KRIPTOGRAFI, Oktober 20. Bandung: Informatika, 2006.

[6] R. K. Hondro, “Analisis Dan Perancangan Sistem Yang Menerapkan Algoritma Triangle Chain Cipher (TCC) Untuk Enkripsi Record Tabel Database,” J. Teknol. Inf. Dan Komun., vol. 3, no. 2, 2014.

[7] R. Munir, Algoritma \& Pemrograman Dalam Bahasa Pascal dan C. Bandung: Informatika, 2011.

[8] T. Zebua, "Analisa Dan Implementasi Algoritma Triangle Chain Pada Penyandian Record Database," Pelita Inform. Budi Darma, vol. 3, no. 2, 2013.

[9] E. Sutoyo, T Mulyanto, Teori Pengolahan Citra Digital. Yogyakarta: Andi, 2009. 